\title{
Верхня Ј-подібна міністернотомія в хірургічному лікуванні патологіі висхідної аорти: особливості хірургічної техніки та аналіз результатів перших 70 операцій
}

\author{
В. В. Вайда, В. І. Кравченко, I. I. Жеков, I. М. Кравченко, В. В. Лазоришинець \\ Національний інститут серцево-судинної хірургії імені М. М. Амосова НАМН України, м. Київ

\section{The upper J-like ministernotomy in surgical treatment technique and analysis of results of first 70 operations} \\ of pathology of aorta ascendance: peculiarities of surgical
}

\author{
V. V. Vayda, V. I. Kravchenko, I. I. Zhekov, I. M. Kravchenko, V. V. Lazoryshynets \\ Amosov National Institute of Cardio-Vascular, Kyiv
}

\section{Реферат}

Мета. Покращити результати хірургічного лікування патології висхідної аорти в поєднанні з ураженням аортального клапана шляхом мінімізації операційної травми

Матеріали і методи. В Національному інституті серцево-судинної хірургії імені М.М. Амосова НАМН України 301.01 .2015 по 01.01.2019 р. оперовано 70 пацієнтів, у яких для доступу використана верхня Ј-подібна міністернотомія.

Результати. Ніхто 3 оперованих паціентів не помер. Механічна вентиляція в середньому тривала $(4,5 \pm 0,5)$ години після втручання. Всі паціенти були переведені з відділення реанімації та інтенсивної терапії протягом $(36 \pm 3,5)$ години після операції. Ускладнення даної методики відмічені у 5 (7,1\%) пацієнтів.

Висновки. Методика корекції аортальних вад серця, поєднаних з аневризмою висхідної аорти, через мініінвазивний доступ може бути в клінічній практиці альтернативою серединній стернотомії.

Ключові слова: міністернотомія; аортальний стеноз; аневризма висхідної аорти; аортальна недостатність.

Abstract

Objective. To improve the results of surgical treatment of the aorta ascendance pathology in combination with affection of aortal valve due to minimization of operative trauma.

Materials and methods. In Amosov National Institute of Cardio-Vascular Surgery in period 01.01.2015 - 01.01.2019 yr 70 patients were operated, in whom the operative access of a J-like ministernotomy was applied.

Results. Operative mortality was absent. Mechanical ventilation after the intervention have lasted $(4.5 \pm 0.5)$ hours. All the patients were delivered to Department of Reanimation and Intensive Therapy during $(36 \pm 3.5)$ hours after the operation. Complications of this procedure were noted in 5 (7.1\%) patients.

Conclusion. The procedure for correction of the aortal heart failures, combined with the aorta ascendance aneurism, using miniinvasive access, may serve as the median sternotomy clinical alternative.

Keywords: ministernotomy; aortal stenosis; aneurism of aorta ascendance; aortal insufficiency.

Найбільш поширеною патологією аорти є ії аневризма. Загальна частота аневризми аорти, за даними різних авторів, становить від 5,9 до 10,4 спостереження на 100 тисяч населення на рік [1]. Найчастіше ця патологія виникає у людей старше 40 років. Аневризми висхідної аорти становлять 45\% від загального числа аневризм аорти всіх локалізацій.

Аневризма - це патологічне місцеве або дифузне розширення артеріальної судини, що зачіпає всі оболонки ії стінки, на 50\% перевищує нормальний діаметр судини і схильне до поширення та розриву. Основний дефект полягає в руйнуванні еластичних волокон середньої оболонки судини, внаслідок чого фіброзна тканина розтягується. Це призводить до збільшення діаметра судини, що у свою чергу викликає напругу ії стінки. Стінка аневризматичного мішка складається практично виключно з фі- брозної тканини. Через неламінарний характер кровотоку утворюються тромби, які сприяють виникненню аневризми зсередини, займаючи більший обсяг. Тромби, що перебувають в аневризматичному мішку, слугують джерелом тромбоемболії в різні дистальні розгалуження аорти. У міру прогресування цього процесу і подальшого розширення просвіту зростає ймовірність розриву. У разі збільшення діаметра аневризми до 6 см і більше ризик розриву різко зростає, що є підставою для використання цього критерію як показання до хірургічного лікування. Як правило, аневризму аорти, незалежно від локалізації, діагностують, якщо поперечний діаметр судини є більшим у $1,5-2$ рази [2].

Єдиний спосіб зберегти життя хворого з даною патологією - хірургічне лікування. Неоперована аневризма висхідної аорти вкрай небезпечна через високий ризик 
розриву і раптової смерті пацієнта після встановлення діагнозу. Протягом двох років ризик розриву аневризми мають близько 70\% пацієнтів, при цьому смертність сягає 95\%. Виживаність протягом 5 - 10 років не перевищує 13 19\%. Госпітальна смертність після реконструкції висхідної частини аорти і аортального клапана становить 3 - 15\%.

За статистикою за останні два десятиліття в багатьох розвинених країнах неухильно зростає загальна кількість операцій на грудній аорті головним чином за рахунок операцій з приводу аневризм і розшарувань грудного відділу аорти. Такий стан речей пояснюється сукупністю причин. По-перше, серед лікарів усіх спеціальностей значно зросла настороженість щодо цих захворювань. По-друге, збільшилися діагностичні можливості розпізнавати патологію на більш ранніх етапах, до розвитку фатальних ускладнень. По-третє, всі дослідники відзначають постійне зростання кількості дегенеративних ушкоджень стінки аорти, пов'язаних з такими факторами, як генетичні аномалії, атеросклероз і гіпертонічна хвороба. І по-четверте, помітні успіхи ряду провідних клінік у лікуванні патології аорти стали запорукою різкого зростання хірургічної активності в багатьох інших кардіохірургічних центрах.

Найбільш частими і небезпечними ускладненнями аневризми є іiі розшарування і розрив, що супроводжується високою смертністю - 50\% хворих помирає в строки до 2 діб, 70\% - упродовж перших двох тижнів. Найбільш критичним $є$ період гострого розшарування, який може призвести до розповсюдження розшарування на всю ділянку аорти від коронарних судин до клубових артерій або зовнішнього розриву аорти з витоком крові у порожнину перикарда, плевральну порожнину. Своєчасне хірургічне лікування розшарування аневризми аорти приводить до значного зниження смертності хворих.

За останні роки мінінвазивні доступи дедалі частіше запроваджують в кардіохірургічній практиці. Враховуючи те що застосування мініінвазивного доступу при корекції захворювань аортального клапана в поєднанні з патологією висхідної аорти пришвидшує функціональне відновлення пацієнтів, необхідні ретельний підхід та єдино правильний вибір методу лікування. Таким чином, проблема вибору доступу при хірургічному лікуванні пацієнтів з патологією аортального клапана та висхідної аорти є актуальною.

У хворих після втручання на висхідній аорті через міністернотомію достовірно менша потреба в переливанні компонентів крові, менші строки перебування у відділенні реанімації та стаціонарі, менш виражений больовий синдром і нижча частота ускладнень з боку грудини, післяопераційної рани. У деяких клініках світу частка подібних втручань сягає 65\%. Очевидно, що більше ніж половина пацієнтів можуть бути оперовані через мінідоступ.

Даний доступ застосовують у пацієнтів усіх вікових категорій з різною масою тіла. Перевагами міністернотомії, окрім відмінного косметичного ефекту і зменшення ризику віддаленої нестабільності грудини, є зменшення ранової поверхні, об'єму крововтрати в порівнянні зі стан- дартною технікою, больових відчуттів, доз наркотичних аналгетиків, кількості виділень по дренажу, тривалості штучної вентиляції легенів у післяопераційному періоді, строків перебування пацієнта в клініці, швидке його повернення до звичного способу життя, у результаті чого істотно знижується вартість лікування.

Але ставлення хірургічної спільноти до застосування мінідоступів при протезуванні висхідної аорти неоднозначне. Основна причина цього - незручності під час операції. Це стосується як візуалізації, так і техніки виконання операції. Крім того, досі результати хірургічного лікування патології аортального клапана в поєднанні 3 аневризмою висхідної аорти та особливості хірургічної техніки з мінінвазивного доступу недостатньо висвітлені в літературі, немає єдиної думки стосовно вибору методу корекції.

Незважаючи на очевидні переваги поздовжньої серединної стернотомії як оперативного доступу до серця при корекції патології висхідної аорти у поєднанні з ураженням аортального клапана та ізольованих розширень висхідної аорти малого діаметра, у поглиблених дослідженнях останніх років повідомляється і про певні недоліки цієї методики, а сучасність ставить перед кардіохірургами вимогу вміти виконувати складні втручання 3 мінімізацією операційної травми, щоб хворий менше часу перебував у стаціонарі.

Мета дослідження: покращення результатів хірургічного лікування патології висхідної аорти в поєднанні з ураженням аортального клапана шляхом мінімізації операційної травми та швидкої фізичної реабілітації пацієнтів.

\section{Матеріали і методи дослідження}

У Національному інституті серцево-судинної хірургії імені М. М. Амосова НАМН України з 01.01.2015 по 01.01.2019 р. оперовано 70 пацієнтів з приводу корекції як ізольованих аневризм висхідної аорти малого діаметра, так і в поєднанні з ураженням аортального клапана. У всіх хворих використана верхня Ј-подібна міністернотомія для доступу.

Всім пацієнтам проведені клінічні й інструментальні методи дослідження: ЕКГ, рентгенографія органів грудної порожнини, ЕхоКГ. Проведено хронометрію загальної тривалості втручання, тривалості штучного кровообігу та перетиснення аорти. Визначено об'єм інтраопераційної крововтрати, кількість гемотрансфузій в операційній і в першу післяопераційну добу. Фіксовано об'єм крововтрати на першу післяопераційну добу, тривалість механічної вентиляції легенів, тривалість перебування пацієнта у відділенні реанімації та інтенсивної терапії.

У залежності від виду оперативного втручання всі пацієнти були розподілені на три групи. Заміну аортального клапана в поєднанні з екзопротезуванням висхідної аорти виконано 45 (64,3\%) хворим (група А); протезування висхідної аорти за різними методиками - 16 (22,9\%) хворим (група Б); ізольоване екзопротезування висхідної аорти на працюючому серці - 9 (12,9\%) хворим (група В). 
У групі Б виконували протезування висхідної аорти за такими методиками: заміна аортального клапана в поєднанні з протезуванням висхідної аорти - 13 пацієнтів, у тому числі одна пацієнтка з розшаруванням висхідної аорти (2 тип за De Bakey), клапанзберігаюче протезування висхідної аорти за методикою Девіда - 2 пацієнти, супракоронарне протезування висхідної аорти при гострій розшаровуючій аневризмі (1 тип за De Bakey) - 1 пацієнт.

Серед оперованих 58 хворих з аортальною вадою й аневризмою висхідної аорти було 45 (77,6\%) чоловіків та 13 (22,4\%) жінок. Вік пацієнтів коливався від 13 до 69 років, у середньому становив $(38 \pm 6,2)$ року. За характером ураження аортального клапана розподіл пацієнтів був таким: переважаючий аортальний стеноз - 37 (63,8\%) пацієнтів, аортальна недостатність - 11 (19\%), комбінована аортальна вада без явної переваги - 10 (17,2\%). У 12 пацієнтів аортальний клапан був інтактний. Аневризма аорти була в межах 44 - 56 мм, середній діаметр становив (49 4) мм. У 2 хворих була аневризма некоронарного синуса Вальсальви (до 52 мм). Серед оперованих хворих 3 ізольованим розширенням висхідної аорти, яким було виконано екзопротезування висхідної аорти на працюючому серці, було 7 (77,8\%) чоловіків і 2 (22,2\%) жінки. Вік хворих коливався від 18 до 48 років, середній вік становив $(32,5 \pm 4,3)$ року.

\section{Результати}

Жоден оперований хворий не помер. Тривалість втручання становила 220 - 380 хв, середня - (285 \pm 33$)$ хв. Середня тривалість перетиснення аорти становила (104 $\pm 28)$ хв. Об'єм інтраопераційної крововтрати у всіх хворих не перевищував 400 мл. Об'єм крововтрати в 1-шу післяопераційну добу становив від 50 до 300 мл, серед-

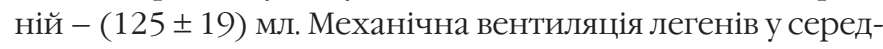
ньому тривала $(4,5 \pm 0,5)$ год після втручання. Всі пацієнти були переведені з відділення реанімації та інтенсивної терапії протягом $(36 \pm 3,5)$ год після операції. У пацієнтів після екзопротезування виконували ехо-контроль (3 та 6 міс) - діаметр висхідної аорти не перевищував 35 - 37 мм. Тобто міграції протеза не відмічено у жодного хворого. У пацієнтів даної групи тривалість операції становила 140 - 240 хв, середня - (163 \pm 15$)$ хв. Діаметр висхідної аорти дорівнював 49 - 55 мм, середній - (52 \pm 3 ) мм. Об'єм крововтрати становив 50 - 200 мл, середній - (135 $\pm 19)$ мл. На ехо-контролі у одного пацієнта з протезованою висхідною аортою (методика Девіда) зафіксовано мінімальний зворотний витік на аортальному клапані, ще у одного - помірну аортальну недостатність.

Ускладнення означеної методики спостерігали у 5 (7,1\%) пацієнтів. За даними клініки в Італії частота ускладнень при використанні даної методики становила 10\% [3].

У 2 пацієнтів ми вимушено вдалися до конверсії доступу у серединну стернотомію. У одного пацієнта виконали реторакотомію. У одного пацієнта після відновлення самостійної серцевої діяльності виник стійкий атріовентрикулярний блок, який потребував імплантації постій- ного водія ритму. У однієї пацієнтки сформувалася нориця з лігатури на грудині, що потребувало ревізії ходу нориці й висічення нитки з грудини та в цілому подовжило строки перебування в стаціонарі до 1 міс з моменту операції. У 2 хворих після переведення на 2-гу післяопераційну добу в умови терапевтичного стаціонару тривав виражений больовий синдром протягом тижня з дня втручання. У решти пацієнтів відзначено більш швидку реабілітацію, менш виражені скарги на больові відчуття, а отже, й меншу потребу у знеболювальних препаратах.

\section{Обговорення}

Хірургічна техніка у разі застосування верхньої J-подібної міністернотомії має свої особливості, детально зупинимося на них. У положенні хворого лежачи на спині розріз шкіри (6 - 8 см) виконували поздовжньо від яремної вирізки до третього (n=61), у деяких пацієнтів до четвертого (n=9) міжреберного проміжку. Грудину розсікали поздовжньо до цього ж рівня, від якого пересікали праворуч у міжребер”і. Після обробки країв грудини гемостатичною губкою встановлювали ретрактор. Перикард відкривали поздовжньо із Т-подібним розсіченням у нижньому краї операційної рани. Краї перикарда фіксували лігатурами.

Для забезпечення штучного кровообігу після введення гепарину канюлювали висхідну частину або дугу аорти залежно від розповсюдження розширення аорти на дистальні відділи їі висхідної частини. У 16 хворих, яким виконували операцію Бенталла, операцію Девіда та супракоронарне протезування висхідної аорти, виконували доступ через ліву стегнову артерію для підключення артеріальної лінії. Двопросвітну венозну канюлю встановлювали у вушко правого передсердя. Лівий шлуночок дренували через гирло правої верхньої легеневої вени. Операції виконували в умовах помірної гіпотермії $\left(32^{\circ} \mathrm{C}\right)$. У пацієнта 3 гострою розшаровуючою аневризмою аорти (1 тип за De Bakey) загальна гіпотермія становила $24{ }^{\circ} \mathrm{C}$. У даному спостереженні після інспекції дуги аорти було прийнято рішення виконати реконструкцію напівдуги аорти в умовах циркуляторного арешту (9 хв). У всіх хворих вдавалося встановити кардіоплегічну канюлю в коронарний синус для забезпечення доставлення кардіоплегічного розчину за комбінованою методикою. Після перетиснення аорти та зупинки серцевої діяльності (комбінована ретроантеградна кардіоплегія, кустодіол, 20 мл/кг) виконували аортотомію, ревізували уражений аортальний клапан, видаляли його та заміняли штучним механічним або біопротезом. При розширеному та зміненому синотубулярному з'єднанні висхідну аорту відсікали та імплантували попередньо зшитий кондуїт, який не обгортали залишками аневризматичного мішка. За необхідності корекції аневризми висхідної аорти 2 - 3 шви із середини некоронарної стулки й один шов із комісури між лівою та правою коронарними стулками виводили назовні аорти на тефлонових смужках. Встановлювали дренажні системи та підшивали електроди перед відновленням серцевої 
діяльності. Після ушивання аорти та профілактики повітряної емболії знімали перетискач з аорти та відновлювали серцеву діяльність. Поступово зігрівали хворого до природних показників температури тіла. На етапі реперфузії для корекції розширення аорти виконували ії обгортання судинним протезом, який фіксували до кільця протеза аортального клапана попередньо виведеними швами та обгортали всю висхідну аорту до діаметра 4,0 - 4,2 см. У 2 хворих з діагностованою аневризмою некоронарного синуса та інтактним аортальним клапаном виконали резекцію висхідної аорти з ії протезуванням за методикою Девіда. Після закінчення штучного кровообігу проводили деканюляцію порожнин серця. Упевнившись у гемостазі, порожнину перикарда ушивали окремими швами, грудину фіксували чотирма окремими швами. На шкіру накладали косметичний шов.

Серед переваг використання мініінвазивної техніки зменшення хірургічної травми, збереження каркасності грудної клітки, що скорочує тривалість лікування пацієнта як у відділенні реанімації, так і в стаціонарі, зниження частоти гнійно-септичних ускладнень, менший об'єм крововтрати. Крім того, на думку М. Masetti і співавторів (1999), якщо розмір і якість післяопераційного рубця є запорукою зниження психологічного стресу пацієнта, на це також варто зважати, плануючи втручання.

До недоліків означеної методики відносимо: утруднену механічну профілактику повітряної емболії; ризик адекватного захисту міокарда; неможливість прямої візуалізації контрактильної здатності лівого шлуночка; судинні ускладнення при периферійній канюляції; ризик інфікування рани.

Значне поєднання типів конституції з варіантами патології серця потребує від хірурга вміння маніпулювати різними видами мінідоступів. У літературі пропонується кілька варіантів вибору методики доступу. Найбілыш простим є використання рентгенографії (F. F. Sardari, 1997; L. K. von Segesser, 1999; L. A. Bockerm, 2001). Використовують також черезстравохідну ЕхоКГ, яку виконують на операційному столі після введення хворого в медикаментозний сон, але до розрізу шкіри (F.F. Sardari, 1997). Та найінформативнішою вважають спіральну комп'ютерну томографія (СКТ), за допомогою якої можна найбільш точно визначити положення серця та його скелетотопію й вибрати оптимальний варіант доступу (R. Armar, 1998). Вибір СКТ для цієї мети оснований на ії точності, неінвазивності, можливості одночасної візуалізації кісткових структур і м'яких тканин, а також визначення просторових взаємовідношень у грудній клітці. Невірно вибраний доступ може стати причиною конвертації розрізу, що певною мірою дискредитує дану методику і може бути підставою для іiї незначного поширення. Різноманітність існуючих доступів потребує визначення чітких показань і протипоказань до їх вибору. Таким чином, розробка алгоритму вибору доступу може сприяти поліпшенню якості кардіохірургічної допомоги.
Кількість повідомлень про виконання мініінвазивних доступів для корекції ізольованих клапанних вад серця натепер достатньо значна, проте застосування цієї методики при корекції аневризми висхідної аорти супроводжується більшими ризиками, а отже, використовують їі не так часто.

\section{Висновки}

Таким чином, описана методика, незважаючи на деякі технічні труднощі на етапі освоєння, дає змогу уникнути недоліків, характерних для поздовжньої серединної стернотоміі. Застосування методу мінімізує хірургічну травму, забезпечує гарний косметичний ефект і може бути у клінічній практиці альтернативою поздовжній стернотомії. Перевагами пропонованої методики заміни аортального клапана в поєднанні з екзопротезуванням висхідної аорти є більша результативність, менша кількість ускладнень, пришвидшена реабілітація хворих і краща якість їх життя в післяопераційному періоді.

\section{Підтвердження}

Фінансування. Власним коштом.

Участь авторів у створенні статті. Вайда В. В. - збір матеріалу, статистичне опрацювання даних, підготовка тексту; Кравченко В. І. - статистичне опрацювання даних, аналіз отриманих результатів; Жеков I. I. - аналіз отриманих результатів; Кравченко I. М. - розробка концепції та дизайну дослідження, аналіз отриманих даних; Лазоришинець В. В. - розробка концепції та дизайну дослідження, аналіз отриманих даних, редагування.

\section{Конфлікт інтересів}

Автори, які взяли участь в цьому дослідженні, заявили, що у них немає конфлікту інтересів щодо цього рукопису.

Згода на публікацію. Всі автори прочитали і схвалили остаточний варіант рукопису. Всі автори дали згоду на публікацію цього рукопису.

\section{References}

1. Abdulkareem N, Soppa G, Jones S, Valencia O, Smelt J, Jahangiri M. Dilatation of the remaining aorta after aortic valve or aortic root replacement in patients with bicuspid aortic valve: a 5-year follow-up. Ann Thorac Surg. 2013;96(1):43-9. doi:10.1016/j.athoracsur.2013.03.086.

2. Sytar LL. Rozsharovuiuchi anevryzmy aorty. In: Sytar LL. Anevryzmy hrudnoi aorty. Ternopil: TDMU «Ukrmedknyha»; 2011. 83-9 s. [In Ukrainian].

3. Roselli EE, Soltesz EG, Mastracci T, Svensson LG, Lytle BW. Antegrade delivery of stent grafts to treat complex thoracic aortic disease. Ann Thorac Surg. 2013;90(2):539-46. doi: 10.12945/j.aorta.2015.14.062.

4. Cutler J, Yacoub M. Minimally invasive techniques in cardiac surgery. J Thorac Cardiovasc Surg. 2015;105(3):435-8. doi: 10.14797/mdcj$12-1-4$.

Надійшла 12.08.2019 